原著

\title{
当院における下肢静脈瘤手術術式の変遷と治療成績
}

\author{
斎藤 聰, 藤田顕弘, 大塚 遼, 神保充孝, 上杉尚正, \\ 小林俊郎, 高橋 剛, 郷良秀典
}

済生会山口総合病院＼cjkstart外科山口市緑町 $2-11 （$ \%753-8517）

Key words：下肢静脈瘤，ストリッピング手術，TLA麻酔，血管内焼灼術

\section{和文抄 録}

【目的】下肢静脈瘤手術は長年ストリッピング手術 が標準術式であったが, 低濃度大量局所浸潤麻酔 (TLA : tumescent local anesthesia) の活用や種々 の工夫により低侵襲化と日帰り手術や早期退院が可 能となった。更に近年は血管内焼灼術（ETA： endovenous thermal ablation）が登場し, 各種波長 のレーザー焼灼術（EVLA： endovenous laser ablation) や高周波焼灼術（RFA： radiofrequency ablation）が保険適用となっている。当院では 2012 年 8 月にETAを導入し現在まで複数の機器を使用 してきたが，これら治療法の妥当性について検討を 行った.

【対象と方法】2012年 8 月から 2020 年 7 月までに当 院で施行した伏在静脈系の下肢静脈瘤手術 1,272 例 のうち，ストリッピング手術（ST群，311例），波 長980nmのレーザーによるEVLA（980nm群， 191 例），波長 $1470 \mathrm{~nm}$ のレーザーによる EVLA (1470nm群，717例)，RFA（RF群，53例）を対象 とし, 各群の手術成績を比較した.

【結果】手術時間はST群が他群より有意に長く, 鎮 痛剂の内服総数と術後皮下出血の頻度はST群と 980nm群が多かった. EHIT (endovenous heatinduced thrombus）の発生率は各群間に有意差は なく, 臨床上問題とされるclass 3 を1470nm群に 4 例認めたが経口抗凝固薬により改善した。いずれの

令和 3 年 1 月 5 日受理
群でも観察期間中の深部静脈血栓症と肺血栓塞栓症 の合併を認めず，静脈の再疎通は $980 \mathrm{~nm}$ 群に 1 例の み認めた。

【結語】当院のストリッピング手術とETAの治療成 績は良好で重篤な合併症もなかった。特に波長 1470nmのレーザーによるEVLAとRFAは手術時間 の短縮と術後疼痛の軽減が得られ, 再疎通はなく有 用な治療法と考えられた。

\section{はじめに}

下肢静脈瘤手術は長年ストリッピング手術が標準 術式であり，かつては全身麻酔や腰椎麻酔で行われ ていた，近年静脈の周囲に低濃度で大量の麻酔薬を 浸潤させる低濃度大量局所浸潤麻酔（TLA： tumescent local anesthesia) 1)を用いることによ り術後早期からの歩行や日帰り手術が可能となっ た。このほかにも内翻式ストリッピング手術 ${ }^{2)}$ や, 静脈溜の切除を小さな皮虐切開で行う stab avulsion 法3) など, 術後疼痛や皮下出血の軽減や手術創の縮 小化のための様々な工夫が報告されており, 当院で も第一選択の手術術式としていた.

一方で血管内治療として, 熱によって静脈を閉塞 し逆流を阻止する血管内焼灼術（ETA： endovenous thermal ablation）が2000年頃より登 場した ${ }^{4}$. 本邦では 2011 年 1 月以降各機器が保険適 応となり，血管内レーザー燒灼術（EVLA： endovenous laser ablation) と高周波（ラジオ波） 焼灼術（RFA：radiofrequency ablation）の 2 つ 
の治療法が広く普及している，当院では 2012 年 8 月 に波長 $980 \mathrm{~nm}$ の半導体レーザー機器である $\mathrm{ELVeS}^{\mathrm{a}}$ レーザー (CeramOptec GmbH, Bonn, Germany) を導入しEVLAによる治療を開始した（図 $1 \mathrm{~A}$ ). 2014年 8 月にはレーザー波長が1470nmになった ELVeS ${ }^{\circledast} レ$ ザー1470（CeramOptec GmbH, Bonn, Germany）に切り替え，2018年10月には高周波治 療機器のエンドヴィーナスクロージャーシステム 3 (Covidien, ev3 Inc, Plymouth, USA) を導入し RFAも施行するようになった（図 $1 \mathrm{~B}$ ).

下肢静脈瘤手術はストリッピング手術の工夫や ETAの登場によって大きく様変わりしており，当

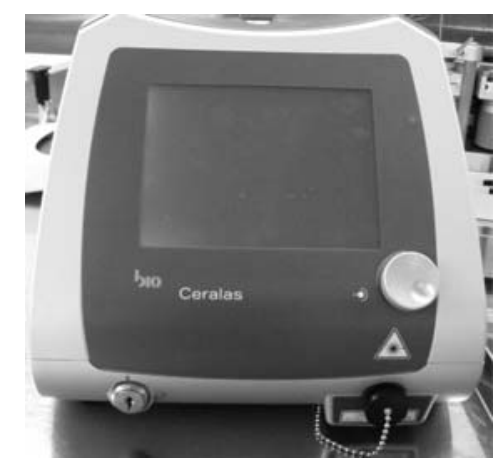

A

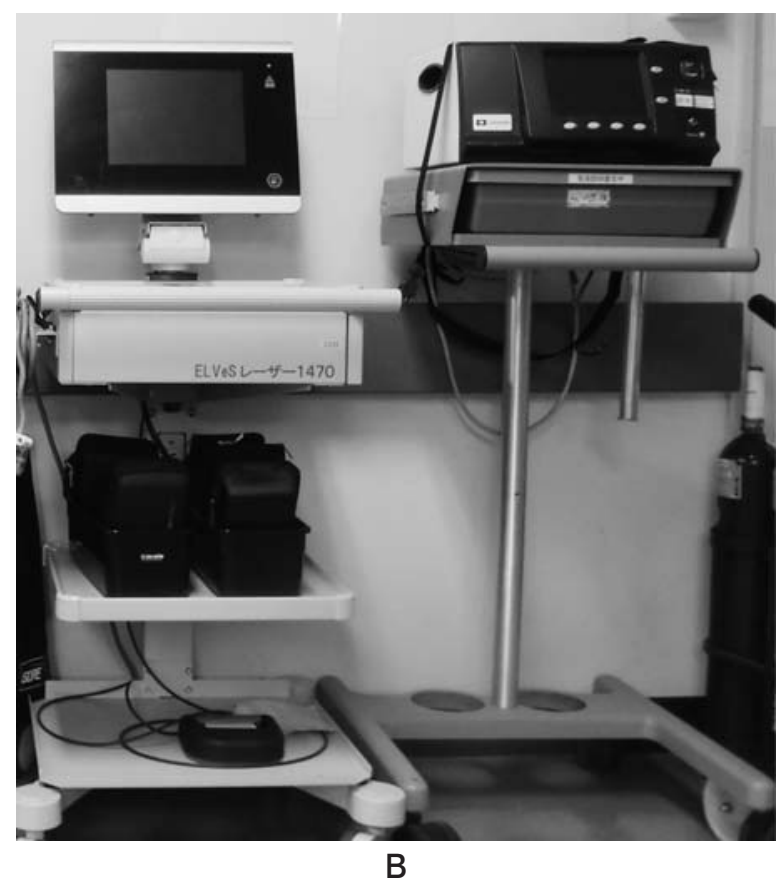

図 1 当院で使用している機器 A : ELVeSレーザー (2012年 8 月から2014年 7 月まで） $\mathrm{B}$ ：左：ELVeSレーザー1470 (2014年 8 月から), 右： エンドヴィーナスクロージャーシステム 3 （2018年10月 から)
院における手術術式と成績を紹介し, 治療法の妥当 性について検討を行う。

対

\section{象}

ETAを導入した 2012 年 8 月から 2020 年 7 月まで の 8 年間に当院で行った伏在静脈系の下肢静脈瘤手 術1,272例のうち，ストリッピング手術（ST群）は

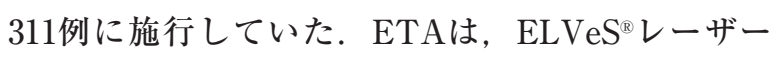
を用いたEVLA（980nm群）は2012年 7 月から 2014 年 7 月までの 2 年間で191例, 後継機種の $\mathrm{ELVeS}^{\circledR} レ$ ーザー1470を用いたEVLA（1470nm群）は2014年 8 月以降の 6 年間で717例, エンドヴィーナスクロ ージャーシステム 3 を用いたRFA（RF群）は2018 年 10 月以降の 1 年 10 力月間で53例に施行していた。

これらの症例を対象とし, 院内臨床研究倫理審查 委員会の承認のもと（承認番号R2-23）後万向き研 究で各群における患者背景と手術のアウトカムを比 較検討した。

\section{方法}

患者背景として(1)年齢, (2)性別, (3)臨床上の重症 度, (4)治療した静脈の種類と (5)静脈径を検討項目と した。(3の重症度は, CEAP分類 ${ }^{5)}$ のclinical分類 (C1６） で評価し， C1 (毛細静脈拡張) からC2 (静脈瘤) PC 3（浮腫）までの皮膚障害がない状態 と, C4（皮膚色素沈着や脂肪皮膚硬化）からC5 （治癒潰瘍）とC6（活動性潰瘍）までの皮虐障害が ある状態の 2 段階に分けた. (4)の静脈の種類とは, 大伏在静脈（GSV：great saphenous vein）と小伏 在静脈 (SSV : small saphenous vein) のことであ り，両方を同時に治療した症例もあった（5)の静脈 径は, 坐位の超音波検查でGSVPSSVの起始部や瘤 を除外した中枢付近の太さが一定となっている部位 で計測した.

また，手術のアウトカムとして各群における(1)手 術時間，(2)stab avulsionの皮虐切開創の数，(3)鎮痛 剂の内服総数, (4)術後の皮下出血と(5)神経障害の頻 度を比較した. (3)の鎮痛剤の内服総数は, 術後 1 力 月間に疼痛に対して頓服したアセトアミノフェン (カロナール) や非ステロイド性消炎鎮痛剤（ロキ ソニン®) の数を合計した值である。 ただし持病の 
関節痛など他疾患での頓服と区別は困難であり，修 正は行わず単純に総数をデータとして採用した．(4) の皮下出血の評価法は, 術後に大腿部や腓腹部の GSVやSSVの領域に視認された皮下出血を, 無, 軽 度，中等度，高度の 4 段階に主観で分類し，中等度 以上を皮下出血ありとした。

更にETAに特有の評価項目として，(1)燒灼を行 った静脈の長さと(2)エネルギー密度（LEED： linear endovenous energy density), (3)血管内焼灼 術による静脈血栓症（EHIT： endovenous heatinduced thrombus）の頻度, (4)媣部静脈血栓症 (DVT : deep vein thrombosis) p肺血栓塞栓症 (PTE : pulmonary thromboembolism) の有無, (5) 焼灼部位の皮膚色素沈着の頻度，6焼灼閉塞させた 静脈の再疎通の有無を比較した。(2)のLEEDはレー ザー焼灼時のエネルギー量の指標になるものであ り，単位長あたりのエネルギー密度 $(\mathrm{J} / \mathrm{cm})$ を算 出した. (3)のEHITと(4)のDVTは, 術後 1 週間以内 と術後 $1 \sim 6$ 力月の期間の最低 2 回超音波検查を行 い評価した. EHITはclass 1 から 4 までに分類され ${ }^{6)}$, 血栓が伏在静脈内にとどまるclass 1 , 深部静脈 内に突出するが $50 \%$ 以上に達していないclass 2 , $50 \%$ 以上に達するclass 3 , 樑部静脈をほぼ閉塞する class 4 があり, class 3 以上が問題にされることが
多い. (4)のPTEの診断法であるが，ルーチンで検 查はしておらず，観察期間中（～6力月）にPTE を疑う胸部症状や下肢DVTがあった場合に造影CT を行う方針とした. (6の再疎通とは，ガイドライン に則り術後 $1 \sim 6$ カ月の超音波検查でGSVやSSVが 起始部から $5 \mathrm{~cm}$ 超えて開存し血流がある場合と した7).

各群間でこれらのデータを比較し, 統計手法は Kruskal-Wallis検定と Steel-Dwass-CritchlowFligner法による多重比較， $\chi^{2}$ 検定と Fisherの正確 確率検定を用いた。

\section{結果}

患者背景として各群の年齢, 性別, CEAP分類, 治療した静脈と静脈径を示した（表 1 )。各群間で 年齢, 性別に差はなく, 理由は不明だが $1470 \mathrm{~nm}$ 群 がST群と $980 \mathrm{~nm}$ 群に比べて皮虐障害を有する CEAP分類C4以上の症例が多かった. GSV とSSVの 割合は，980nm群が初期にSSVに治療を行っていな かったためかST群と有意差があり，RF群はSSVに 実施していないため他群と有意差があった。静脈径 は980nm群が他群より細く1470nm群もST群より細 かったが，これは静脈径が細い症例を積極的に

表 1 各群における患者背景

\begin{tabular}{|c|c|c|c|c|c|}
\hline & $\begin{array}{l}\text { ST群 } \\
\text { (311例) }\end{array}$ & $\begin{array}{c}980 \text { nm群 } \\
\text { (191例) }\end{array}$ & $\begin{array}{c}\text { 1470nm群 } \\
\text { (717例) }\end{array}$ & $\begin{array}{l}\text { RF群 } \\
\text { (53例) }\end{array}$ & p值 \\
\hline 年齢 [歳] & $65.7 \pm 10.5$ & $65.8 \pm 12.4$ & $66.4 \pm 11.7$ & $65.7 \pm 11.1$ & 0.391 \\
\hline 男:女 & $101: 210$ & $55: 136$ & $225: 492$ & $22: 33$ & 0.621 \\
\hline $\begin{array}{r}\text { CEAP分類 } \mathrm{C} 1-3 \text { [例 }] \\
\text { C4-6 [例 }]\end{array}$ & $\begin{array}{r}252 \\
59\end{array}$ & $\begin{array}{r}166 \\
25\end{array}$ & $\begin{array}{l}518 \\
199\end{array}$ & $\begin{array}{l}40 \\
13\end{array}$ & $<0.0001$ \\
\hline $\begin{array}{l}\text { 大伏在静脈 [肢] } \\
\text { 小伏在静脈 [肢] }\end{array}$ & $\begin{array}{r}262 \\
54\end{array}$ & $\begin{array}{r}179 \\
19\end{array}$ & $\begin{array}{l}628 \\
120\end{array}$ & $\begin{array}{r}53 \\
0\end{array}$ & 0.0002 \\
\hline 静脈径 [mm] & 7. $7 \pm 2.0$ & $6.2 \pm 1.1$ & 7. $0 \pm 1.7$ & 7. $3 \pm 2.0$ & $<0.0001$ * \\
\hline
\end{tabular}

年齢と静脈径は平均值士標準偏差で表示。

* 1470nm群 vs. ST群 $\mathrm{p}=0.003,1470 \mathrm{~nm}$ 群 vs. $980 \mathrm{~nm}$ 群 $\mathrm{p}<0.0001$

** 980nm群 vs. ST群 $\mathrm{p}=0.02$, RF群 vs. ST群 $\mathrm{p}=0.0002$, RF群 vs. $980 \mathrm{~nm}$ 群 $\mathrm{p}=0.02$, RF群 vs. $1470 \mathrm{~nm}$ 群 $\mathrm{p}=0.0002$

*** 980 群 vs. ST群 p $<0.0001$, 980群 vs. $1470 \mathrm{~nm}$ 群 p $<0.0001$, 980群 vs. RF群 $\mathrm{p}=0.0002,1470 \mathrm{~nm}$ 群 vs. ST群 $\mathrm{p}<0.0001$

各群間で年齢，性別に有意差はなかったが，CEAP分類は1470nm群がST群と $980 \mathrm{~nm}$ 群に比べてC4以上の症例が多かった. 小伏在静脈の割合は980nm群がST群より少なく, RF群も他群より少なかった. 静脈径は $980 \mathrm{~nm}$ 群が他群より細く, $1470 \mathrm{~nm}$ 群もST群より細かった。 
EVLAの適応にしたためと考えられた。

次に各群の手術のアウトカムとして, 手術時間と stab avulsionの皮膚切開数，治療期間中の鎮痛剂の 内服総数, 術後の皮下出血, 神経障害の有無を比較 した (表 2 )。手術時間はST群が他群より有意に長 かったがstab avulsionの皮膚切開数は各群間で差は なく, 手術時間の差は静脈本幹の治療手技にかかっ た時間の差と考えられた。鎮痛剂の内服総数は $980 \mathrm{~nm}$ 群 $>$ ST 群 $>1470 \mathrm{~nm}$ 群 $\fallingdotseq \mathrm{RF}$ 群の順に多く, 1470nmレーザーを用いたEVLAとRFAは術後の疼

表 2 各群の手術条件と術後合併症

\begin{tabular}{|c|c|c|c|c|c|}
\hline & $\begin{array}{l}\text { ST群 } \\
\text { (311例) }\end{array}$ & $\begin{array}{l}\text { 980nm群 } \\
\text { (191例) }\end{array}$ & $\begin{array}{c}\text { 1470nm群 } \\
\text { (717例) }\end{array}$ & $\begin{array}{l}\text { RF群 } \\
\text { (53例) }\end{array}$ & p值 \\
\hline 手術時間 [分] & $63.3 \pm 21.6$ & 41. $1 \pm 14.8$ & $39.3 \pm 17.1$ & $40.5 \pm 17.5$ & $<0.0001 *$ \\
\hline Stab avulsion [ヶ所] & 4. $8 \pm 3.2$ & 4. $7 \pm 2.9$ & 4. $4 \pm 3.2$ & 4. $1 \pm 3.0$ & 0.265 \\
\hline 鎮痛剤内服数［錠］ & $1.6 \pm 3.5$ & $4.8 \pm 8.1$ & $0.8 \pm 2.8$ & $0.6 \pm 1.7$ & $<0.0001 * *$ \\
\hline 皮下出血［例］ & $\begin{array}{c}118 \\
(37.9 \%)\end{array}$ & $\begin{array}{c}92 \\
(48.2 \%)\end{array}$ & $\begin{array}{c}28 \\
(3.9 \%)\end{array}$ & $\begin{array}{c}3 \\
(5.7 \%)\end{array}$ & $<0.0001 * * *$ \\
\hline 神経障害 [例］ & $(0.3 \%)$ & $\begin{array}{c}0 \\
(0 \%)\end{array}$ & $\begin{array}{c}{ }^{7} \\
(1.0 \%)\end{array}$ & $\begin{array}{c}1 \\
(1.9 \%)\end{array}$ & 0.240 \\
\hline
\end{tabular}

手術時間とstab avulsion数と鎮痛剂内服数は平均值土標準偏差で表示。

* ST群 vs. $980 \mathrm{~nm}$ 群 p $<0.0001$, ST群 vs. $1470 \mathrm{~nm}$ 群 p $<0.0001$, ST群 vs. RF群 p $<0.0001$

** $980 \mathrm{~nm}$ 群 vs. ST群 $\mathrm{p}<0.0001,980 \mathrm{~nm}$ 群 vs. $1470 \mathrm{~nm}$ 群 $\mathrm{p}<0.0001,980 \mathrm{~nm}$ 群 vs. RF群 $\mathrm{p}<0.0001$, ST群 vs. $1470 \mathrm{~nm}$ 群 $\mathrm{p}<0.0001$, ST群 vs. RF群 $\mathrm{p}=0.002$ *** ST群 vs. $1470 \mathrm{~nm}$ 群 $\mathrm{p}<0.0001$, ST群 vs. RF群 $\mathrm{p}<0.0001$, 980nm群 vs. $1470 \mathrm{~nm}$ 群 $\mathrm{p}<0.0001$, 980nm群 vs. RF群 $\mathrm{p}<0.0001$

手術時間はST群が他群より長かったがstab avulsion数は各群間で差はなかった。鎮痛剤の内服総数は980nm群＞ST群＞ 1470nm群 $\fallingdotseq \mathrm{RF}$ 群の順に多かった。皮下出血はST群と980nm群が1470nm群とRF群より多かった．神経障害は各群間で有意 差はなかった.

表 3 各群の焼灼条件と焼灼後合併症

\begin{tabular}{|c|c|c|c|c|}
\hline & $\begin{array}{l}980 \text { nm群 } \\
\text { (191例) }\end{array}$ & $\begin{array}{l}\text { 1470nm群 } \\
\text { (717例) }\end{array}$ & $\begin{array}{l}\text { RF群 } \\
\text { (53例) }\end{array}$ & p值 \\
\hline 焼灼長 $[\mathrm{cm}]$ & $33.6 \pm 10.5$ & $36.7 \pm 12.8$ & $44.4 \pm 8.8$ & $<0.0001 *$ \\
\hline LEED $[\mathrm{J} / \mathrm{cm}]$ & $76.5 \pm 8.1$ & $76.3 \pm 9.9$ & - & 0.570 \\
\hline EHIT class 2 [例] & $\begin{array}{c}3 \\
(1.6 \%)\end{array}$ & $\begin{array}{c}13 \\
(1.8 \%)\end{array}$ & $\begin{array}{c}0 \\
0 \%\end{array}$ & \\
\hline class 3 [例] & $\begin{array}{c}0 \\
(0 \%)\end{array}$ & $\begin{array}{c}4 \\
(0.6 \%)\end{array}$ & $\begin{array}{c}0 \\
(0 \%)\end{array}$ & 0.936 \\
\hline class 4 [例] & $\begin{array}{c}0 \\
(0 \%)\end{array}$ & $\begin{array}{c}0 \\
(0 \%)\end{array}$ & $\begin{array}{c}0 \\
(0 \%) \\
\end{array}$ & \\
\hline DVT/PTE［例］ & $\begin{array}{l}0 / 0 \\
(0 \%)\end{array}$ & $\begin{array}{l}0 / 0 \\
(0 \%)\end{array}$ & $\begin{array}{l}0 / 0 \\
(0 \%)\end{array}$ & - \\
\hline 皮膚色素沈着 [例] & $\begin{array}{c}1 \\
(0.5 \%)\end{array}$ & $\begin{array}{c}21 \\
(2.9 \%)\end{array}$ & $\begin{array}{c}0 \\
(0 \%)\end{array}$ & 0.080 \\
\hline 静脈再疎通 [例] & $\begin{array}{c}1 \\
(0.5 \%)\end{array}$ & $\begin{array}{c}0 \\
(0 \%)\end{array}$ & $\begin{array}{c}0 \\
(0 \%)\end{array}$ & 0.253 \\
\hline
\end{tabular}

LEED: linear endovenous energy density, EHIT: endovenous heat-induced thrombus DVT: deep vein thrombosis, PTE: pulmonary thromboembolism 焼灼長とLEEDは平均值士標準偏差で表示。

* 980nm群 vs. 1470 nm群 p $<0.0001$ ，980nm群 vs. RF群 p<0.0001，1470nm群 vs. RF群 p $<0.0001$

焼灼長はRF群>1470nm群>980nm群の順で長かったが, LEED (linear endovenous energy density) に有意差はなかった。 EHIT (endovenous heat-induced thrombus) の発生率は各群間に有意差はなく，静脈血栓塞栓症の合併症はなかった。皮 膚色素沈着の頻度は各群間で有意差はなく，静脈の再疎通は980nm群に 1 例のみ認めた. 
痛が少ないことが示された。また， 1 回も鎮痛片を 使わなかった症例の割合は $980 \mathrm{~nm}$ 群 $34.6 \%$, ST群 $51.8 \% ， 1470 \mathrm{~nm}$ 群 $75.5 \%$, RF群 $79.2 \%$ あり, 当院 で施行した症例の多くに痛みがなかったことが示唆 された，皮下出血は術後 1 週間前後をピークに認め られ，頻度はST群が $37.9 \%, 980 \mathrm{~nm}$ 群が48.2\%であ り，1470nm群の $3.9 \%$ とF群の $5.7 \%$ りも有意に多 かった。静脈抜去や焼灼による術後神経障害は $1 \%$ 前後にみられたが各群で有意差はなかった，神経障 害の種類としてはSSV治療時の脛骨神経麻痺のよう な重篤なものはなく, 伏在神経や腓腹神経領域のし びれや知覚鈍麻であった。

更にETAの各群において燒灼条件, EHITの頻度, DVTやPTEの有無, 皮虐色素沈着の頻度, 再疎通 の有無を比較した（表 3 ）。焼灼長はRF群 $>1460 \mathrm{~nm}$ 群 $>980 \mathrm{~nm}$ 群の順で長かった。これは焼灼長の最小 〜最大值が $1470 \mathrm{~nm}$ 群は $4 \sim 63 \mathrm{~cm}$ と短い症例が含ま れているのに対し， RF群は $23 \sim 62 \mathrm{~cm}$ と短い症例に は実施していなかったことと，980nm群は10〜 $52 \mathrm{~cm}$ と ETA導入間も無い時期で治療長が長い症例 が少なかったためと考えられた．レーザーに特有の 指標であるLEEDは980nm群と1470n群でともに $70 \mathrm{~J} / \mathrm{cm}$ 台で有意差はなかった。 EHITの発生率は各 群間に有意差はなく, 臨床上問題とされる class 3 を $1470 \mathrm{~nm}$ 群に4 例認めたが経口抗凝固薬 (DOAC : direct oral anticoagulants) 内服により それぞれ $1 ， 2 ， 3 ， 6$ 週間目に血栓は消失した。 またいずれの群でもEHITの class 4 やDVTの合併 を認めなかった。観察期間中にPTEを疑う胸部症 状を生じて造影CTを施行した例もなかった，静脈 が浅く皮虐表面近くを走行している部位を焼灼する と皮膚色素沈着を来すことがあり, $1470 \mathrm{~nm}$ 群は 21 例 $(2.9 \%)$ に認めたが軽度であり，各群間に有意差 もなかった，焼灼後の静脈の再疎通は $980 \mathrm{~nm}$ 群に 1 例のみ認めた。また比較検討項目ではないが, stab avulsionを除いたETAの手技は全例皮膚切開では なく経皮的静脈穿刺で実施できていた。

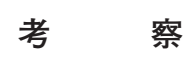

\section{ストリッピング手術のエ夫}

下肢静脈瘤のストリッピング手術は 100 年以上前 から行われてきた方法で, 少ない再発率と安定した

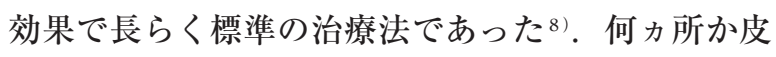
虐を切開し逆流や瘤化のある静脈を露出しストリッ パーを挿入したのち抜去するという術式であり，治 療が下肢の広い範囲に及ぶためかつては全身麻醉や 腰椎麻酔で行われ入院治療が必要であった。TLA はもともと脂肪吸引術の麻酔に用いられていたが近 年下肢静脈瘤手術に用いられるようになり当院では 2011年 3 月から導入した ${ }^{1)}$. $0.05 \sim 0.1 \%$ の低濃度リ ドカインにアドレナリンを添加した局所麻酔であ り, アドレナリンによる血管収縮とリドカイン吸収 抑制により大量の麻醉薬が使用でき組織からの出血. 軽隇の効果もあり下肢静脈手術に適している。麻醉 液の組成の一例を次に示す（生理食塩水 $500 \mathrm{ml}+$ 工 ピネフリン含有 $1 \%$ ネシロカイン $40 \mathrm{ml}+7 \%$ メイロ ン $10 \mathrm{ml}$ ） 7). 超音波ガイド下に伏在静脈を確認しな がら周囲に $20 \mathrm{G} / 7 \mathrm{~cm}$ 長のカテラン針を刺入し麻醉 薬を注入すると, 伏在静脈は筋膜に囲まれた saphenous compartment内を走行しているためコ ンパートメント内に麻酔薬が浸潤し広がっていく. 当院の工夫として, 少しでも針の刺入時の痛みと穿 刺回数と針痕を少なくするため $21 \mathrm{G} / 12 \mathrm{~cm}$ の専用の カテラン針 (八光メディカル, 長野) を用いている. 局所麻酔薬は上述の組成に準じて約 $300 \mathrm{ml}$ 作成し (生理食塩水 $250 \mathrm{ml} / 1$ 袋にエピネフリン含有 $0.5 \%$ キ シロカイン $40 \mathrm{ml}$ と $8.4 \%$ メイン $10 \mathrm{ml}$ を添加), 輸液 ルートを接続し途中の三方活栓とシリンジを用いて 助手に用手的に麻酔薬を注入してもらっている（図 $2 \mathrm{~A})$. 超音波診断装置は外来診療で使う大型のも のではなく, 麻酔科医が神経ブロックや中心静脈穿 刺用に手術室に常備している比較的小型の機器であ るSonoSite S-Nerveと13-6MHzリニアプローブ（ソ ノサイト・ジャパン, 東京）を使用し, 術者は左手 で超音波プローブを持ち右手でカテラン針を操作す る (図 2 B). 更に麻醉科医の管理下にプロポフォ ールによる静脈麻酔を併用し, 術中の患者の不安と 穿刺時の痛みの軽減と鎮静を得ている。

静脈の抜去は以前はストリッパー先端の弾丸状の ヘッドで静脈をひっかけてアコーディオン状に引き 抜くバブコック法が行われていたが (図 $3 \mathrm{~A}$ ), へ ッドによる周囲組織の損傷による神経障害や皮下出 血が問題であった，当院では静脈は全長を抜去する のではなく超音波検查で逆流のある範囲を選択的に 抜去する方針としており，特に下腿末梢のGSVや 
SSVは伏在神経や腓腹神経が隣接し神経損傷のリス クがあるため無用な抜去は避けるようにしている。 手術中は臥位となり静脈の拡張や逆流が認識しにく くなるため, 治療範囲は術前に坐位の超音波検査で マーキングしなければならない.

内翻式ストリッピングは静脈を内翻させながら抜 去することで周囲の損傷を軽減でき有効性が報告さ れていたが2), 内翻用のJMSデイスポーザブル静脈 ストリッパー（ジェイ・エム・エス，広島）がディ スポーザブル器具のため当院では散発的な施行に留

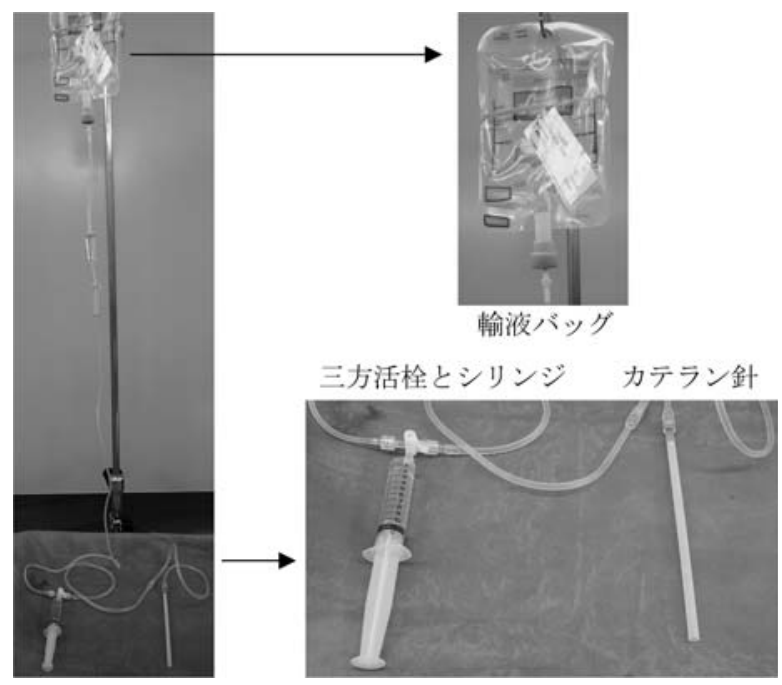

A

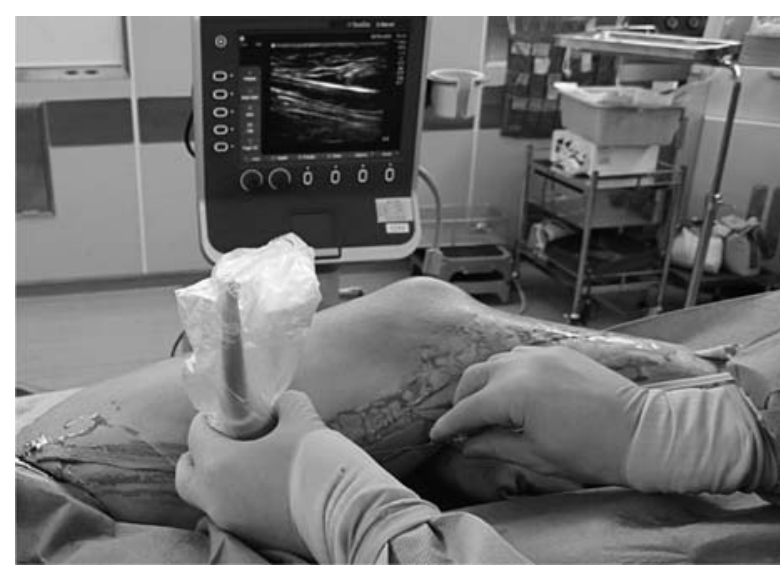

B

図2 低濃度大量局所浸潤麻酔（TLA：tumescent local anesthesia)

A：局所麻酔薬をバッグ内に作成し輸液セットをつなぎ, ルートの途中に三方活栓とシリンジ，先端にカテラン針 を接続する. 左 : 全体像, 右 : 拡大写真.

B : 術者は左手で超音波プローブを持ち右手でカテラン 針を操作し, 超音波ガイド下に静脈周囲にカテラン針を 刺入する．助手がルート途中の三方活栓とシリンジを用 いて麻酔薬を注入する。
まっていた（図 3 B). しかし通常のリユースでき るバブコック法のストリッパーに点滴用の延長チュ ーブを接続することで代用できることがわかり9) 2011年 3 月から内翻式ストリッピングを標準術式と した。以上の方法で静脈を抜去すると内翻式ストリ ッピングとTLAの効果で抜去時の出血が少なく, 抜去部の用手的圧迫止血もほとんど行っていない.

ストリッピング手術において鼠径部での高位結䅨 の手技は重要で，GSV中枢が残存すると同部の分枝 から再発する危惧があるため ${ }^{10)}$ 可及的に高位で本幹 を処理し分枝も結紮切離するように心がけている. また下腿などの分枝の静脈瘤の処理については逆流 のある本幹を処理すれば分枝の切除は必須ではない との考えもあるが，当院では2008年から $2 \mathrm{~mm}$ 前後の 皮膚小切開と専用フックを用いて瘤を切除する stab avulsion法 ${ }^{3)}$ で目立つ部分は治療している（図 4 A). 創が小さいため縫合はほとんどの場合不要でサージ カルテープで固定を行っている．当院で使用してい るフックは現在製造されていないが複数の企業から 様々な種類のフックが販売されている（図 4B).

以上のように当院では(1)麻酔はTLAで，(2)選択的
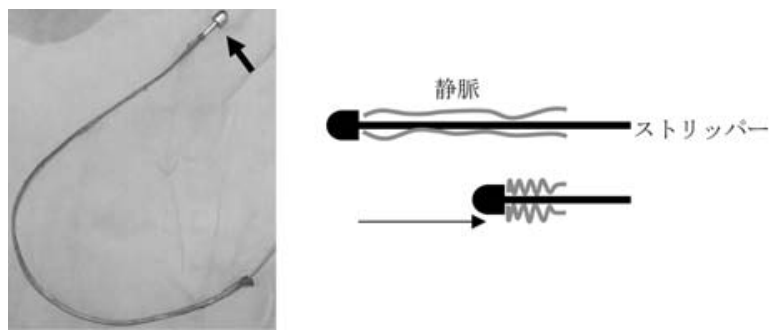

A

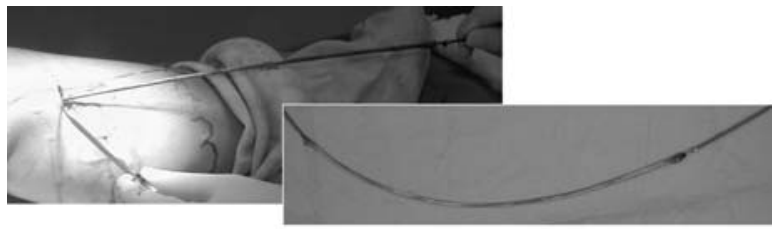

静脈

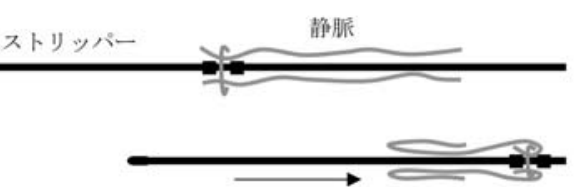

B

図３ストリッピング手術

$\mathrm{A} ：$ バブコック法：ストリッパー先端の弾丸状のヘッド (矢印) で静脈をひっかけてアコーディオン状に引き抜く. $\mathrm{B}$ ：内翻法：内翻式ストリッパーを用いて静脈を内翻さ せながら引き抜く。 
範囲の伏在静脈を, (3)内翻式ストリッピングし, (4) 高位結㮃を確実に行い, (5)分枝瘤切除はstab avulsion法を用いることで，術後早期からの歩行や日 帰り手術が可能となりしばらくは第一選択の治療法 としていた。このたびの検討で, 術後疼痛は $980 \mathrm{~nm}$ レーザーを用いたEVLAよりも少ないことが示され， 静脈抜去による神経障害も軽度なもののが 1 例 $0.3 \%$ に留まった。下肢静脈瘤手術の合併症として DVT/PTEが $0.31 \%$ ，腓骨神経障害が $0.10 \%$ ，動脈損傷 が $0.1 \%$ との報告や ${ }^{11)}$ 医原性血管損傷が 0.0017 ～ $0.3 \%$ と の報告 ${ }^{12)}$ があるが，当院のストリッピング手術で大

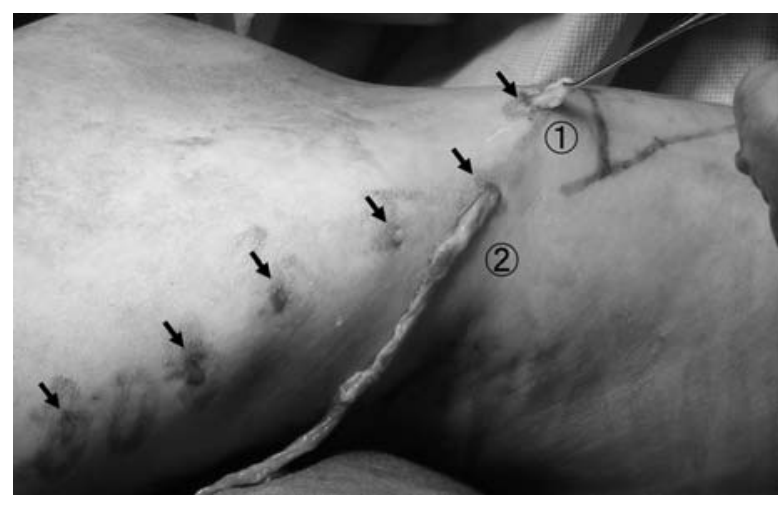

A
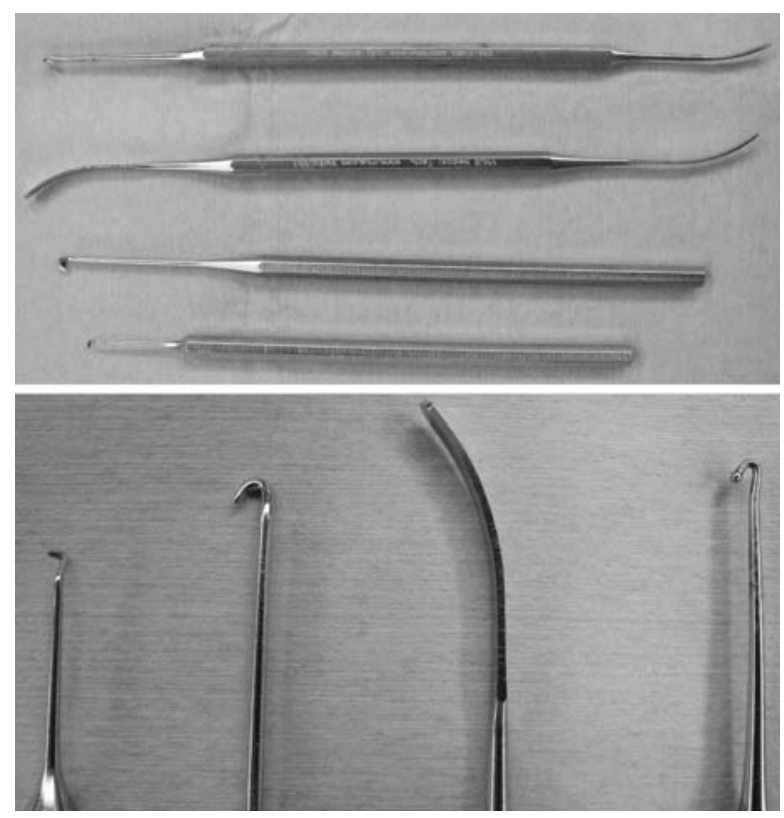

B

図4 Stab avulsion

A : 静脈瘤直上の皮膚に複数の小さな皮膚切開を加え (矢印), フックを用いて静脈瘤を引き出す（1)フックで裹 引中の静脈，(2)途中まで抜去した静脈)。

$\mathrm{B}: \mathrm{Stab}$ avulsion用の各種フック（上図）とその先端 (下図).
出血, DVTやPTE, 高度な神経障害などの重篤な合 併症はなく, 侵襲の軽減や安全性が確認された。

\section{血管内治療の登場}

ストリッピング手術に工夫がなされる一方で近 年, 血管内治療が急速に普及してきており，レーザ 一を用いるEVLAと高周波を用いるRFAの 2 つが 主流になっている. ELVAは2001年ごろより下肢静 脈瘤の治療に取り入られるようになったが4,13), 日 本では長らく保険適応がなくようやく2011年 1 月に

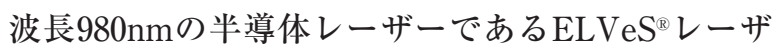
一が保険適応となった. ファイバーの先端がベアチ ップでレーザー光が長軸方向に照射されるため血管 壁を直接焼灼できず術後の疼痛や皮下出血が多いと

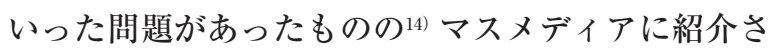
れ日本で下肢静脈瘤という疾患が広く認知されるこ ととなった。2014年には波長1470nmの半導体レー

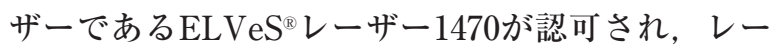
ザーが先端の 2 カ所から全周性に照射されるラディ アルファイバー（Radial 2ring fiber）の採用と （図 5 A）波長が1470nmになったことで静脈壁を効 率的に焼灼できるようになった ${ }^{15,16)}$ 。なおEVLA施 行にあたってはクラス 4 の医療用レーザーであるた め日本工業規格の安全基準に基づきレーザー管理区 域の設定，ゴーグルによる目の保護などの安全対策 が必要である。

EVLAの手技であるがまず超音波ガイド下に末梢 の静脈を穿刺し6Frシースを中枢に向けて留置す る.当院の結果で特筆すべき点として, stab avulsionを除き全例経皮的静脈穿刺で施行できたこ とがあげられるが，穿刺に失敗すると血腫や血管の スパズムによりますます穿刺が困難となり皮膚切開 を加え静脈を露出せねばならなくなるため, 穿刺に はある程度の習熟と細心の注意を払う必要がある。 次に光ファイバー（Radial 2ring fiber）をシース から焼灼予定の静脈中枢まで扦入し，ストリッピン グ手術と同様に治療範囲にTLAによる麻酔を行う. TLAを静脈周囲に浸潤させることで，熱焼灼によ る疼痛や周囲組織の熱傷を防ぐだけでなく静脈内径 を減少させ焼灼効率を高めることができる，続いて レーザーを照射しながらファイバーを末梢に率引し つつ静脈を焼灼していく（図 5 B，C）が, レーザ 一の出力は $6 \sim 12 \mathrm{~W}$ で牽引速度により静脈 $1 \mathrm{~cm}$ 長 
に対して 60 ～80Jになるようなエネルギー密度 (LEED) での焼灼が標準的である。レーザーのエ ネルギーは出力と照射時間で計算され連続発振レー

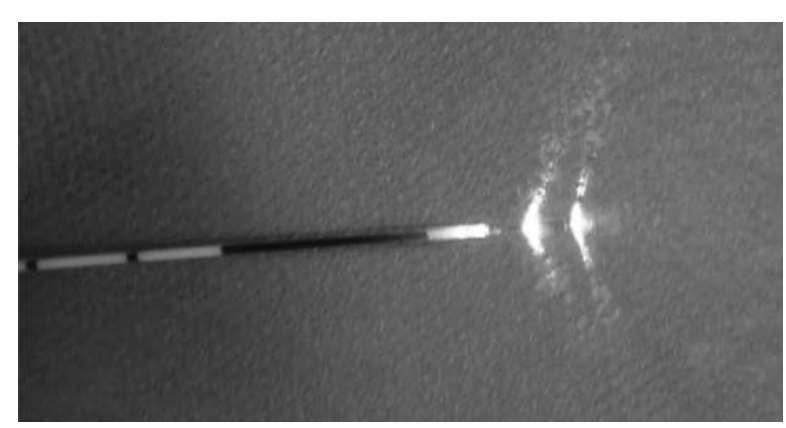

A

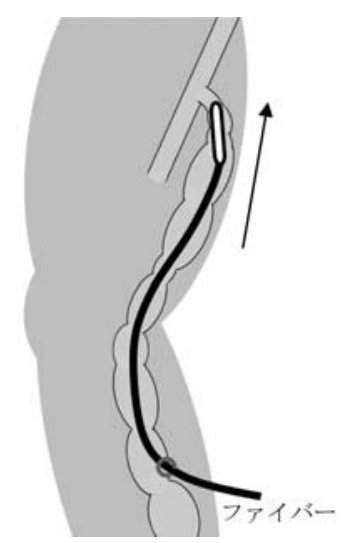

B

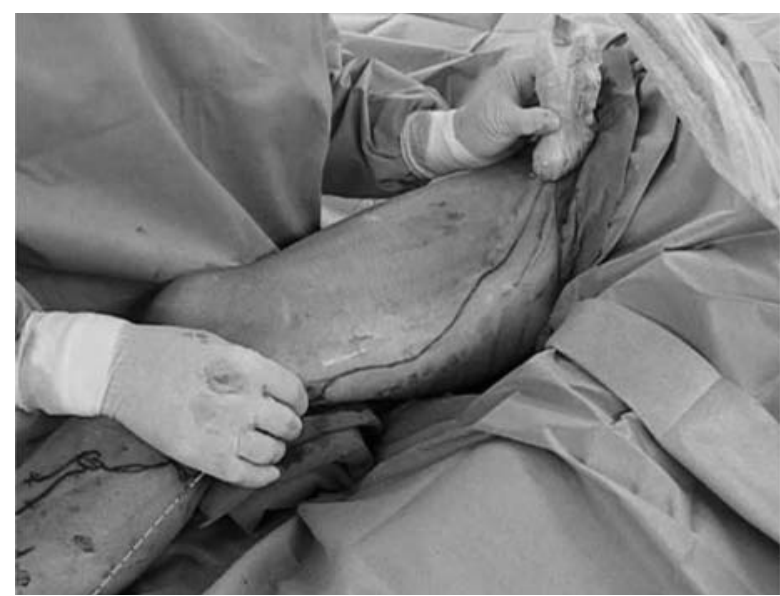

D

図5 血管内レーザー燒灼術（EVLA：endovenous laser ablation)

A ：Radial 2ring fiber先端.レーザーが 2 カ所から全周性 に焼灼される。

B：ファイバーを焼灼予定の静脈の中枢まで挿入する.

C : レーザーを照射しながら未梢に牽引しつつ静脈を燒 灼していく.

$\mathrm{D}$ ：術者は左手で超音波プローブを持ち右手でファイバ 一を操作し血管内焼灼を行う。ファイバーの旁引速度に より燒灼の密度を調節する。
ザーの場合 $1 \mathrm{~W}=1 \mathrm{~J}$ /秒となるため, 出力 $10 \mathrm{~W} ら ~$ ば 7 秒間で $1 \mathrm{~cm}$ 旁引した場合, LEEDは $70 \mathrm{~J} / \mathrm{cm}$ と なる．当院では 60 回 $/ 60$ 秒にセットしたメトロノー ムの音を指標に用手的にファイバーを劧引している が，早すぎたり遲すぎないように引くにはある程度 の慣れが必要である。またLEEDは $70 \mathrm{~J} / \mathrm{cm}$ 目安 にして右手でファイバーを牽引しているが，焼灼中 も左手の超音波プローブで焼灼の状況をリアルタイ ムに確認しながら牽引速度を調節している（図 5 D). その後，末梢の分枝静脈瘤はストリッピング 手術と同様にstab avulsionを行う。なお2018年には 細径のファイバー（Radial 2ring slim fiber）が認 可され，6Frシースが不要でより細い16G静脈留置 針から挿入できるようになった，末梢の分枝静脈瘤 をシースレスで複数箇所の穿刺で燒灼可能なため, 皮虐硬化が強く皮虐切開による瘤切除がためらわれ る部位の静脈瘤治療に有効と考えている。

高周波による血管内治療法であるRFAは, 1998 年より欧米で認可され広く普及したが17)，わが国で は2014年にようやくエンドヴィーナスクロージャー システム 3 が保険適用となったＥVVLA同様に良好 な成績が報告されており ${ }^{18,19)}$, 高周波発生装置 (ClosureRFG ${ }^{\mathrm{TM}}$ Generator) は周波数 $400 \sim 480 \mathrm{kHz}$ の高周波電流を出力し, カテーテル (ClosureFAST ${ }^{\mathrm{TM}}$ ) は先端に $7 \mathrm{~cm}$ 長の発熱部を有し $120^{\circ} \mathrm{C}$ に自動的に調節され静脈壁を燒灼する（図 6 A)。 RFAの手技であるが7Frのシースを留置した のちにカテーテル (ClosureFAST ${ }^{\mathrm{TM})}$ を静脈の中 枢まで挿入しTLAを行う。次にカテーテル先端の 発熱部を超音波で視認しながらプローブで圧迫し， 静脈壁と密着させ 20 秒間焼灼しては牽引し分節的に 焼灼閉鎖していく（図 $6 \mathrm{~B}$ )。プローブは $4 \mathrm{~cm}$ 程度 の大きさで $7 \mathrm{~cm}$ の発熱部全長を圧迫できないため, 当院では術者は左手の超音波プローブでカテーテル 先端を圧迫し右手でスイッチを押して焼灼を開始し たのち右手でも圧迫している（図6C）.

RFAはカテーテル内にガイドワイヤーを通せる ため挿入時の補助にできる，レーザー光を用いない ためレーザー管理区域の設定やゴーグル等による目 の保護が不要, カテーテルを固定して20秒ごとに分 節燒灼するためEVLAのように常時牽引しなくても よいため手技がやりやすいといった点がメリットと 思われる。一方でシースの太さが7Frであり EVLA 
に比べて穿刺痕が大きくなる，焼灼時に超音波プロ ーブで圧迫を行うため静脈が浅い症例では皮膚と静 脈が近くなり皮膚熱傷の懸念がある，カテーテル先 端の発熱部が $7 \mathrm{~cm}$ 長のためSSVなどの短い範囲の 焼灼に不向き，といったデメリットが挙げられる。 2016年に先端発熱部が $3 \mathrm{~cm}$ 長のカテーテルが登場 したが，当院ではSSVや治療長が短い症例はEVLA で対処可能なため採用していない.

\section{EVLAとRFAの成績}

当院では 2012 年 8 月に $\mathrm{ELVeS}^{\circledR} レ$ ザーを導入 し，980nmレーザーとベアチップファイバーによる EVLAを開始した。2014年 8 月に後継機種の $\mathrm{ELVeS}^{\circledR}$ レーザー1470を導入し1470nmレーザーとラ ディアルファイバーによるEVLAに切り替え, 2018年10月にはエンドヴィーナスクロージャーシス テム 3 を導入しRFAも施行するようになった。 EVLAとRFAの使い分けであるが，レーザーの管

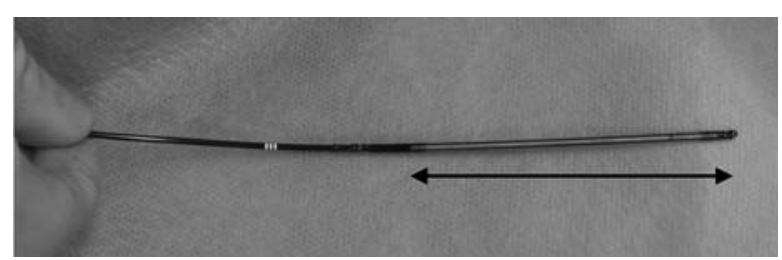

A

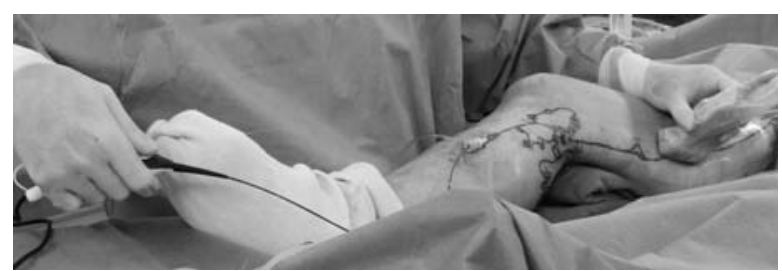

B

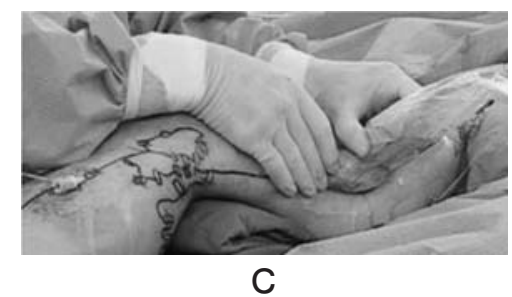

図6 高周波焼灼術（RFA：radiofrequency ablation） A : ClosureFAST ${ }^{\mathrm{TM}}$ 先端. $7 \mathrm{~cm}$ 長の発熱部（矢印）を有 する.

$\mathrm{B}$ ：静脈内に挿入したカテーテル先端の発熱部を左手の 超音波プローブで圧迫し静脈壁と密着させ，右手でスイ ッチを押して焼灼を開始する。

$\mathrm{C}$ : 超音波プローブは $4 \mathrm{~cm}$ 程度の大きさで $7 \mathrm{~cm}$ の発熱部 全長を圧迫できないため, 焼灼開始直後から右手でも圧 迫する。
理が不要なRFAをまずは検討するようにしている。 しかし(1)皮膚障害や美容的な理由でシースの穿刺痕 を少しでも小さくしたい場合，(2GSVやSSVが浅い 症例，3SSVや治療長が短い症例はEVLAを選択し ている，当院でRFAを採用した2018年10月以降の EVLAとRFAの症例数の比率は，162:53でEVLA が多かったがこの比率は術者や施設により異なって いると思われる.

このたびの検討で, EVLAとRFAはストリッピ ング手術より手術時間が有意に短かった，ストリッ ピングの手術時間は39.7分 ${ }^{9)}$ や46分10) といった報告 はあったが，各施設によりまちまちであり一般的に は30-60分台と推定される. 当院の手術時間は決し て短いとは言えないがTLAの施行時間や，高位結 禁やstab avulsionを念入りに行っていることなどを 勘案すると許容範囲と思われる。一方でEVLAと RFAはストリッピング手術例とstab avulsionの皮 膚切開数は有意差がなかったことから, 純粋に高位 結紮の手技を省略できることが手術時間の短縮につ ながったと考えられた。EVLAの手術時間は34.9分 や36分といった報告があり ${ }^{14,15)}$, 当院の結果も近い ものであった。 なお静脈の焼灼時間のみの比較では RFAがEVLAより有意に短かった (146秒 vs. 266秒) との報告があるが19), 当院の手術時間はEVLAと RFAで有意差はなくTLAやstab avulsionの時間を 合わせると誤差範囲に過ぎないのかもしれない.

980nmレーザーはファイバーの先端がベアチップ でレーザー光が長軸方向に照射されるため血管壁を 直接焼灼できず血栓性静脈炎や静脈壁の穿孔が起こ りやすく，術後にあらかじめ鎮痛剤を内服しても25 〜38.4\%に疼痛があり，57.1～65.0\%に皮下出血があ ったと報告されている ${ }^{14,16)}$. 当院でも, 術式選択の 際に静脈瘤が高度な症例はストリッピング手術を選 択するといったバイアスがかかっていた可能性があ るにもかかわらず，鎮痛剤の内服総数はストリッピ ング手術以上であり，皮下出血も $48.2 \%$ に認められ ストリッピング手術の $37.9 \%$ と同レベルであった。 手術時間が短い, stab avulsion以外の皮膚切開が不 要といったメリットはあるものの術後疼痛や皮下出 血が多いことから，この当時には当院ではEVLAを 第一選択の治療法にはしていなかった。

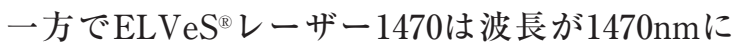
なったことでレーザーエネルギーが水によく吸収さ 
れ静脈壁へ効率よく深達しラデイアルファイバーに より静脈壁全周を均一に焼灼することが可能とな り, 術後の疼痛は $0 \sim 1.3 \%$, 皮下出血の頻度は 0 7.0\%に減ったと報告されている15, 16, 19). 更にRFAも 疼痛が $0.3 \%$, 皮下出血の頻度が $0.9 \%$ と良好な成績が 報告されている ${ }^{19}$ ．これらの報告は術後にあらかじ め鎮痛剤を内服してもらっての結果であり，鎮痛剤 の頓服回数で評価する当院の評価法とは単純には比 較ができないが，平均内服数が 1 回未満， 7 割以上 が 1 回も鎮痛剤を内服しなかったという当院の成績 は遜色ないものと考える。また皮下出血も1470nm レーザーで $3.9 \%$ ， RFAで5.7\%と，ストリッピング や980nmレーザーより少なくなっており諸家の報告 と同様であった。

静脈抜去や燒灼による術後神経障害は $1 \%$ 前後に みられたが各群で有意差はなかった，神経障害の種 類としてはSSV治療時の脛骨神経麻痺のような重篤 なものはなく, 伏在神経や腓腹神経領域のしびれや 知覚鈍麻であった。宇藤らはEVLA後の神経障害を $3.1 \%$ と報告しており ${ }^{20)}$ 当院の成績は劣っているもの ではなかった.

ETAで最も注意を要する合併症はDVTとPTEで あるが，頻度は海外の52研究を検討したメタアナリ シスでDVT 0.3\%, PTE 0.1\%と報告されており ${ }^{211}$, International Union of Phlebology (IUP) 後援の ガイドラインでも DVT，PTEともに0.01\%未満〜 $0.1 \%$ とされている ${ }^{222}$. 我が国での調査ではDVTの 頻度が $0.076 \%$, PTEが $0.0067 \%$ あり ${ }^{23}$ ，当院でも 観察期間中の重篤な血栓症はなく安全性が確認され た。また焼灼端から媣部静脈内に血栓が進展する EHITの頻度は海外では $1.4 \%{ }^{21}$ ，我が国ではclass 2 が $1.0 \%$ ，class 3 が $0.11 \%$ ， class 4 が $0.013 \%$ と報告さ れており ${ }^{23)}$ ，当院の成績も大きく乘離するものでは なかった．当院では全例に最低でも術後 1 週間以内 と 1 力月目以降の 2 回ほど超音波検査を行ってお り, 1 週間以内の検查で臨床上問題とされる class 3 を1470nm群に 4 例発見した. DOAC内服により それぞれ $1 ， 2 ， 3 ， 6$ 週間目に血栓は消失してお り, 術後の超音波検查はEHITの早期発見早期治療 に貢献したと考えられた。ただしEHITがDVTや PTEに発展することは稀であり術後早期の超音波 検查の必要性は少ないといった意見もあり ${ }^{24)}$, スク リーニング法や治療方針は定まってない点も多い.
静脈が浅く皮膚表面近くを走行している部位を焼 灼する場合，TLAを浸潤させて静脈と皮虐の距離 を $1 \mathrm{~cm}$ 以上にしても術後に皮膚色素沈着を来すこ とがある。発生のメカニズムは不明で頻度は $1 \%$ 以 上〜 10\%未満と考えられ7) 美容的な不満につながる ことがある，当院でも $1470 \mathrm{~nm}$ 群の 21 例 $2.9 \%$ に認め たが，RFAは当院の選択基準で静脈が浅い症例に は行っていないため 1 例もなく, $980 \mathrm{~nm}$ レーザー使 用時期にはこのような症例はストリッピング手術を 選択することが多かったため 1 例に認めるのみであ った。一方で1470nmレーザーでは静脈が浅い症例 でも術前に色素沈着の可能性について説明の上で適 応外とはせずに施行したため上記の結果となった が，各治療群間に有意差はなく容認される合併症と 言えるかもしれない.

焼灼後の静脈の再疎通は $980 \mathrm{~nm}$ 群に 1 例の夕認め

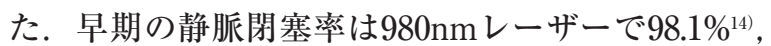
1470nmレーザーで $99.8 〜 100 \%{ }^{15,16,19)}$ ， RFAで 99.7 〜 100\%\%17, 18, 19) と諸家からも良好な成績が報告さ れている。長期成績についても 5 年以上経過を観察 したランダム化比較試験 9 編のシステマティックレ ビューで静脈瘤再発率は $36.6 \%$ ストリッピング手 術の $33.3 \%$ 同等であることが示されている ${ }^{25}$.

当院では $1470 \mathrm{~nm}$ レーザーやRFAの導入以降, ETAを下肢静脈瘤手術の第一選択としてきたが, このたびの検討結果から治療方針は妥当と考えられ た．全国的にもETAを第一選択とする施設が増え ており ${ }^{26}$, 術式や機器も年々洗練され静脈瘤治療の ひとつの解答にたどり着いたと言えるかもしれな い，一方で新たな治療法として熱焼灼およびTLA を用いないことでより低侵襲化を目指した非焼灼非 浸潤麻酔治療（NTNT： non-thermal nontumescent treatment）が登場した。その中でも医 療用接着剂を用いる NBCA（n-butyl-2cyanoacrylate）治療は良好な成績が報告されてお $り^{27)}$, VenaSeal ${ }^{\mathrm{TM}}$ Closure System (Medtronic, Minneapolis, USA）は2019年より本邦でも保険収 載された．当院でも2020年 4 月より使用しており, こちらの成績も今後注目してゆきたい.

\section{結 語}

下肢静脈瘤の手術術式はTLAやETAの登場によ 
り大きく様変わりしたが，当院のストリッピング手 術とETAの治療成績は良好で重篤な合併症もなか った。特に波長1470nmレーザーを用いたEVLAと RFAは手術時間を短縮し術後の疼痛や皮下出血の 軽減が得られ再疎通はなかった。当院では近年, ETAを下肢静脈瘤手術の第一選択としていたが治 療方針は妥当と考えられた。今後も新たなデバイス や薬剤によりさらに低侵襲で安全な治療法が登場す ることが期待される.

\section{利益相反の開示}

本論文において著者および共著者全員に利益相反 はない。

\section{引用文献}

1) Proebstle TM, Paepcke U, Weisel G, et al. High ligation and stripping of the long saphenous vein using the tumescent technique for local anesthesia. Dermatol Surg $1998 ; 24: 149-153$.

2 ) 清水康廣, 杉山 悟, 松森秀之, 清水敏成. 試 作ストリッピングワイヤーによる選択的内翻ス トリッピング法の検討. 日血外会誌 1999 ; 8 : 649-653.

3 ) 山本 崇. Stab Avulsion uo to Date. 静脈学 2017 ; $28: 329-335$.

4) Navarro L, Min RJ, Boné C. Endovenous laser : a new minimally invasive method of treatment for varicose veins--preliminary observations using an $810 \mathrm{~nm}$ diode laser. Dermatol Surg 2001 ; 27 : 117-122.

5 ) Eklöf B, Rutherford RB, Bergan JJ, et al. Revision of the CEAP classification for chronic venous disorders : A consensus statement. J Vasc Surg 2004 ; 40 : 1248-1252.

6 ）広川雅之. 合併症とその対策. 下肢静脈瘤血管 内焼灼術 レーザーおよび高周波焼灼術. 第 2 版. 日本医事新報社。東京, $2016 ； 113-118$.

7 ）広川雅之, 佐戸川弘之, 八杉 巧, 他. 下肢静 脈瘤に対する血管内焼灼術のガイドライン 2019. 静脈学 $2019 ; 30: 19-21$.
8 ) Neglén P, Einarsson E, Eklöf B. The functional long-term value of different types of treatment for saphenous vein incompetence. $J$ Cardiovasc Surg 1993 ; 34 : 295-301.

9 ) 宇藤純一, 塚本芳春, 信岡博済. 再利用可能な Nabatoff型ベインストリッパーを応用した内翻式 ストリッピング手術. 静脈学 $2014 ; 25$ : 410-414.

10）小窪正樹, 野坂哲也, 星野丈夫. 下肢静脈瘤に 対する局所麻酔と静脈麻酔の併用による日㷌り 伏在静脈ストリッピング手術. 静脈学 1999 ; $10: 37-42$.

11) Critchley G, Handa A, Maw A, et al. Complication of varicose vei surgery. Ann $R$ Coll Surg Engl 1997 ; 79 : 105-11.

12) Rudstrom H, Bjorck M, Bergqvist D. Iatrogenic vascular injury in varicose vein surgery : a systemic review. World J Surg 2007 ; $31: 228-233$.

13）小田勝志, 松本康久, 前田博教, 他. エンドレ ーザー法を用いた下肢静脈瘤に対する新しい低 侵襲手術の景観. 脈管学 $2003 ; 43: 27-31$.

14）広川雅之, 栗原伸久。下肢静脈瘤に対する 980nmレーザーを用いた標準的血管内レーザー 治療. 日血外会誌 $2012 ; 21: 583-588$.

15）栗原伸久, 広川雅之. 波長 $1470 \mathrm{~nm}$ レーザーお よびradial 2ring fiberを用いた下肢静脈瘤に対 する血管内レーザー焼灼術 -その初期成績一。 静脈学 $2015 ; 26: 34-40$.

16) Hirokawa M, Ogawa T, Sugawara H, et al. Comparison of $1470 \mathrm{~nm}$ Laser and Radial 2ring Fiber with $980 \mathrm{~nm}$ Laser and Bare- Tip Fiber in Endovenous Laser Ablation of Saphenous Varicose Veins : A Multicenter, Prospective, Randomized, Non- Blind Study. Ann Vasc Dis $2015 ; 8$ : 282-289.

17) Proebstle TM, Alm BJ, Göckeritz O, et al. Five-year results from the prospective European multicentre cohort study on radiofrequency segmental thermal ablation for incompetent great saphenous veins. $\mathrm{Br} J$ Surg $2015 ; 102: 212-218$.

18）白石恭史. 大伏在静脈瘤に対する $\mathrm{VNUS}^{\circledR}$ ClosureFAST Тм るる高周波焼灼術の中期成 
績. 静脈学 $2014 ; 25: 285-290$.

19）山本 崇, 栗原伸久, 広川雅之。下肢静脈瘤に 対する波長1470nmレーザーおよび高周波によ る血管内焼灼術の初期成績. 静脈学 2016 ; $27: 275-280$.

20）宇藤純一, 塚本芳春. 血管内レーザー焼灼術後の 神経障害に関する検討. 静脈学 $2020 ； 31: 65-68$.

21) Healy DA, Kimura S, Power D, et al. A Systematic Review and Meta-analysis of Thrombotic Events Following Endovenous Thermal Ablation of the Great Saphenous Vein. Eur J Vasc Endovasc Surg 2018 ; 56 : 410-424.

22) Pavlović MD, Schuller-Petrović S, Pichot O, et al. Guidelines of the First International Consensus Conference on Endovenous Thermal Ablation for Varicose Vein DiseaseETAV Consensus Meeting 2012. Phlebology $2015 ; 30: 257-227$.

23) Nemoto H, Mo M, Ito $T$, et al. Venous thromboembolic complications after endovenous laser ablation for varicose veins and role of duplex ultrasound scan. $J$ Vasc Surg Venous Lymphat Disord 2019 ; 7 : 817-823.

24) Jones RT, Kabnick LS. Perioperative duplex ultrasound following endothermal ablation of the saphenous vein : is it worthless?. J Invasive Cardiol $2014 ; 26$ : 548-550.

25) Kheirelseid EAH, Crowe G, Sehgal R, et al. Systematic review and meta-analysis of randomized controlled trials evaluating longterm outcomes of endovenous management of lower extremity varicose veins. $J$ Vasc Surg Venous Lymphat Disord 2018 ; 6 : 256-270.

26）佐戸川弘之, 八巻 隆, 岩田博英, 他. 一次性 下肢静脈瘤の治療一本邦における静脈疾患に関 するSurveyXVII-. 静脈学 $2016 ; 27: 249-257$.

27) Gibson K, Morrison N, Kolluri R, et al. Twenty-four month results from a randomized trial of cyanoacrylate closure versus radiofrequency ablation for the treatment of incompetent great saphenous veins. J Vasc Surg Venous Lymphat Disord $2018 ; 6: 606-613$.
Advances in Surgical Procedures for Varicose Veins and Treatment Outcomes at Our Hospital

Satoshi SAITO, Akihiro FUJITA,

Ryo OTSUKA, Mitsutaka JINBO,

Naomasa UESUGI, Toshiro KOBAYASHI,

Tsuyoshi TAKAHASHI and Hidenori GOHRA

Department of Surgery, Saiseikai Yamaguchi General Hospital, 2-11 Midorimachi, Yamaguchi, Yamaguchi 753-8517, Japan

\section{SUMMARY}

Tumescent local anesthesia can alleviate the burden of varicose vein surgery, while endovenous thermal ablation is a new treatment, and endovenous laser ablation ( EVLA) and radiofrequency ablation ( $\mathrm{RFA}$ ) are becoming common due to their recent inclusion in insurance coverage. In this study, surgical outcomes were compared among patients who underwent varicose vein stripping (ST group, 311 patients), EVLA using a laser with wavelengths of $980 \mathrm{~nm}(980 \mathrm{~nm}$ group, 191 patients) and $1470 \mathrm{~nm}$ (1470 nm group, 717 patients), and RFA (RF group, 53 patients). The operation time was significantly longer in the ST group than in the other groups, and pain and bruising were higher in the ST and $980 \mathrm{~nm}$ groups. There were no significant differences in the incidences of endovenous heat-induced thrombosis in all groups. Class 3 events were observed in 4 patients in the $1470 \mathrm{~nm}$ group, but were improved by oral anticoagulants. Complications of thromboembolism did not occur in any group, and venous recanalization was required in only one patient in the $980 \mathrm{~nm}$ group. These results show that $1470 \mathrm{~nm}$ EVLA and RFA shortened the operation time and reduced postoperative pain without causing serious complications, which suggests that these procedures are useful for treatment of varicose veins. 